\title{
Bucculatrix brunnella sp. n. (Lepidoptera, Bucculatricidae) from Sicily and Sardinia
}

\author{
ZDENKo TOKÁR ${ }^{1}$, Aleš LAŠTU゚VKA ${ }^{2}$ \\ 1 P. J. Šafárika 11, SK-92700 Šala, Slovakia: zdeno.tokar@gmail.com \\ 2 Slavíčkova 15, CZ-79601 Prostějov, Czech Republic: aleslastuvkaento@seznam.cz \\ http://zoobank.org/E028C42F-F180-4829-8112-EC3C7B18C9A0
}

Received 7 December 2017; accepted 13 March 2018; published: 18 April 2018

Subject Editor: Carlos Lopez Vaamonde.

\begin{abstract}
Bucculatrix brunnella sp. n. is described from Sicily and Sardinia. The male of the new species is characterized by the almost monochrome ochreous brown forewing. It may resemble the monochrome form of B. cristatella (Zeller, 1839), but the colour of the forewing of the latter species is pale ochreous grey. The female of the new species is slightly smaller, paler and with more conspicuous pattern on the forewing than those of the male. B. brunnella sp. n. differs markedly in the male genitalia from other known Bucculatrix species. The immature stages are unknown. The male and female adults, and genitalia of both sexes, are figured and a distribution map is provided.
\end{abstract}

\section{Introduction}

About 300 species of the family Bucculatricidae are known worldwide, the great majority of which belong to the genus Bucculatrix Zeller, 1839. From the Nearctic region 103 species from this genus are listed by Pohl et al. (2018), approximately the same number occur in the Palaearctic region, and 55 species of these are currently recognised in Europe (Baryshnikova 2013; Mey 2013; Tokár 2017).

Bucculatrix adults are usually very similar in coloration and forewing pattern and, moreover, differences in the genitalia structures in closely related species are often small. For these reasons, and with the significant contribution of genetic analyses, it can be expected that the number of European species will be higher.

However, species which are distinctly different from other known species are found rarely within the European fauna of this genus. One such species was found on the Italian islands of Sicily and Sardinia.

During two visits to Sicily in June 1995 and 2000, when the second author with his brother Zdeněk catalogued the Lepidoptera fauna of the island, they found several males of an unknown Bucculatrix species at three localities in the vicinity of Mount Etna. Some years later, specimens of the unknown species were given to the first author for detailed study. An examination of these males showed that they belonged to a hitherto undescribed Bucculatrix species.

The first author attempted to obtain additional material, especially a female of this species from other private and museum collections. He found two more males in the Klimesch collection (Zoologische Staatssammlung München). Later, he finally obtained through Dr Paolo Triberti (Museo Civico di Storia Naturale in Verona) two females, one of which is from Sicily and second from Sardinia.

Thus, after obtaining both sexes, it was possible to proceed to the description of the new species. 


\title{
Material and methods
}

All specimens of the new species were taken as adults, most of them having been attracted to light-traps.

The genitalia were dissected in the usual way for small Lepidoptera, the preparations being stored in glycerol in small plastic vials or embedded in Euparal on glass slides. The drawings of the adults were made by the second author using water colours. Drawings of the genitalia were made by the first author using Indian ink on transparent sheets.

\author{
Abbreviations \\ AL Aleš Laštůvka \\ BOLD Barcode of Life Data Systems \\ Gen. pr. Genitalia preparation \\ MCVR Museo Civico di Storia Naturale, Verona, Italy \\ ZSM Zoologische Staatssammlung München, Germany \\ ZT Zdenko Tokár
}

\section{Systematics}

\section{Bucculatrix brunnella sp. $\mathrm{n}$.}

http://zoobank.org/D37F0D7A-550D-4F34-9280-B43E906A76C6

Material. Holotype: $\widehat{\jmath}$, pinned, with genitalia in glycerol in a small plastic vial. Original labels: "Italy, Sicily, Francavilla di Sicilia, 37.943921 N; 15.119141 E, 23.vi.2000, leg. A. Laštůvka”, “Gen. pr. ZT đ 10305”, "DNA sample 22860 Lepid Phyl”, "HOLOTYPE Bucculatrix brunnella Tokár \& A. Laštůvka” (red label), coll. A. Laštůvka (will later be deposited in the Moravian Museum in Brno).

Paratypes: $5 \hat{\jmath}$, same locality and data as holotype, Gen. pr. ZT $\delta$ 10762, 11099, AL leg., DNA samples 19427, 22861 Lepid Phyl, coll. AL (4ठ) \& ZT (1ठ); 2ð, same locality as holotype, 14.vi.2000, Gen. pr. ZT

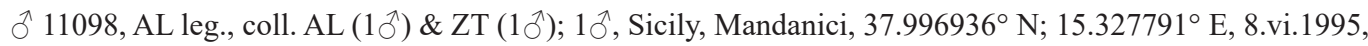
AL leg. \& coll.; $1{ }^{\lambda}$, Mt. Etna, Monte Arso, 37.688501 ${ }^{\circ} \mathrm{N}$; $14.933521^{\circ}$ E, 21.vi.2000, DNA sample 24291 Lepid Phyl, AL leg., coll. ZT; 1 , Mt. Etna, Nicolosi, 1100 m, loc. Camercia (L), 20.vi.2008, slide TRB 3993 †, DNA sample 24276 Lepid Phyl, P. Triberti \& G. Baldizzone leg., coll. MCVR; 1ð̊, Mistretta, Mercuore, 700 m, 10.-20.vi.1952, Gen. pr. ZT đ̊ 13162, 1ð, 21.-30.vi.1952, J. Klimesch leg., coll. ZSM; 1, Sardinia, Gennargentu, Desulo - Tonara, 800 m, 21.ix.1974, slide TRB 3418 ㅇ, F. Hartig leg., coll. MCVR. All paratypes with red labels "PARATYPE Bucculatrix brunnella Tokár \& A. Laštůvka".

Description. Adult, male (Fig. 1). Wingspan 7.0-7.5 mm. Head: frons creamy light brown, vertex with yellow scale tufts, mixed with ochreous to dark brown. Antenna dark brown, eye-caps yellow to ochreous. Thorax, tegulae and ground colour of forewing ochreous to brown. Forewing pattern consisting of scattered dark brown scales, forming more or less diffused marks: one on costa at four-fifths to five-sixths, another on dorsum at three-quarters and a subapical spot broadened towards apex. Cilia tinged with grey. Hindwing and cilia grey.

Female (Fig. 2). Two examined females were smaller (wingspan $6.5 \mathrm{~mm}$ ) and generally paler than males. Antenna ochreous annulated dark brown. Eye-caps creamy white. Thorax, tegulae and ground colour of forewing ochreous. Forewing with more conspicuous pattern than those of male, 


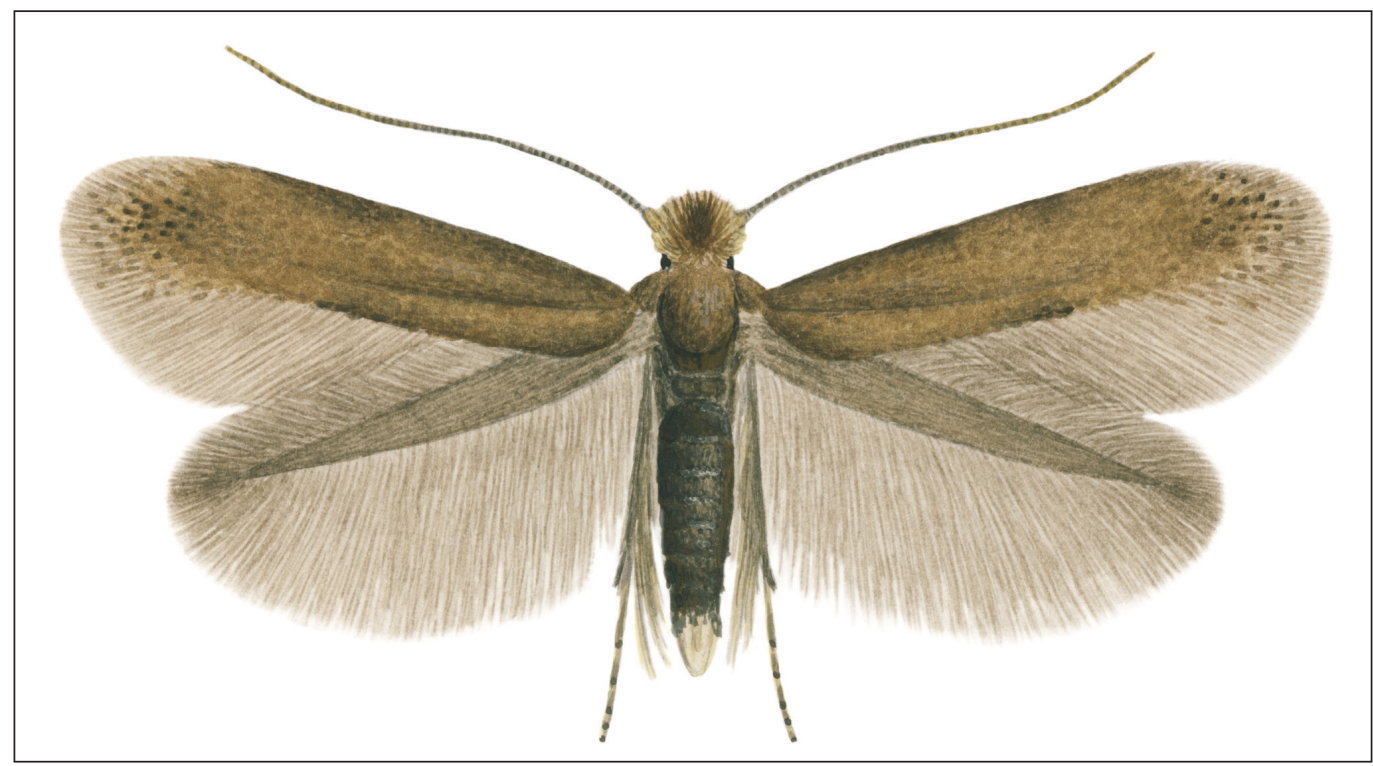

Figure 1. Bucculatrix brunnella sp. n., male, holotype, Francavilla di Sicilia, 23.vi.2000, wingspan 7.5 mm.

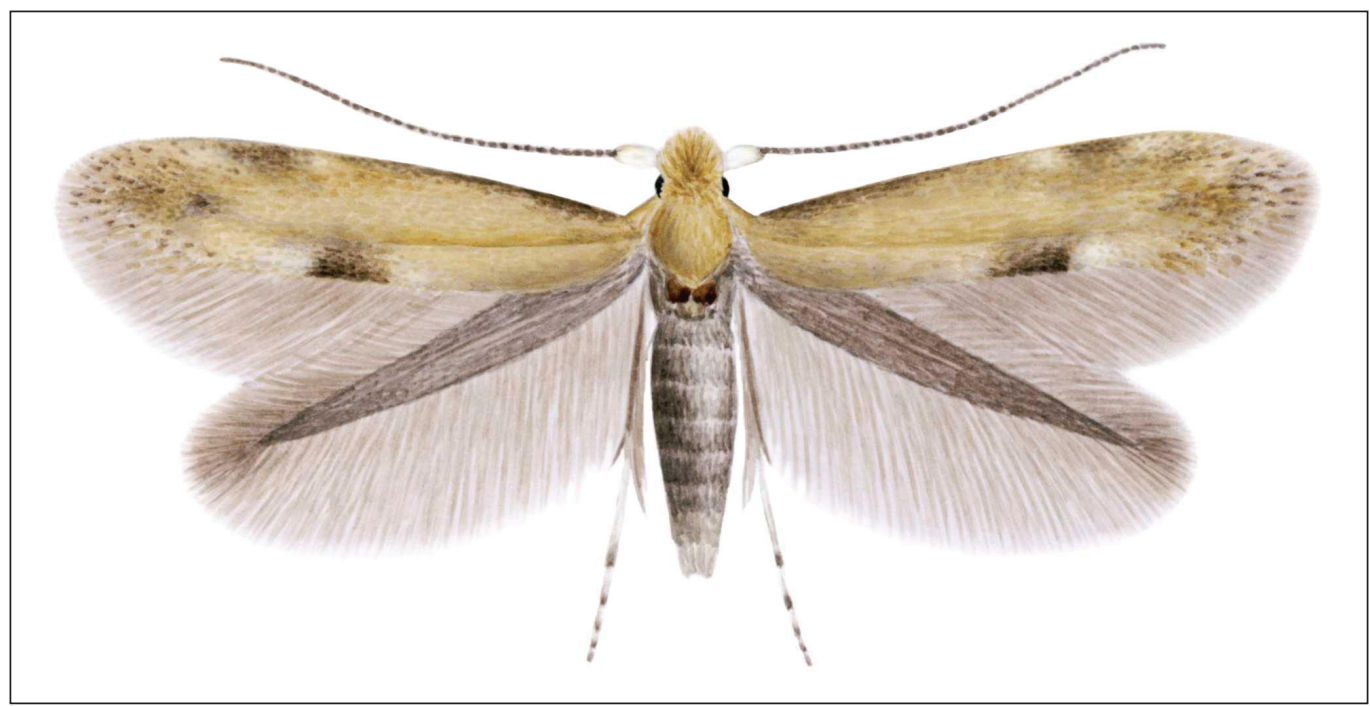

Figure 2. Bucculatrix brunnella sp. n., female, paratype, Mount Etna, Nicolosi, 20.vi.2008, wingspan 6.5 mm.

costa narrowly edged dark brown to three-fifths, and with dark brown spot at the end edged from creamy white to light ochreous, some brown apical scales, a conspicuous dark brown dorsal spot edged creamy white to light ochreous at three-quarters and a dark brown subapical spot.

Male genitalia (Fig. 3). Uncus and gnathos absent. Socii developed to form two slender setose lobes, moderately enlarging at the rounded apex. Vinculum relatively narrow, elongated. Valva slender, gradually tapering distad from base to a pointed apex. Several short stout setae at apex. Phallus long, slender tube swollen at base, 2.7 times longer than valva. 


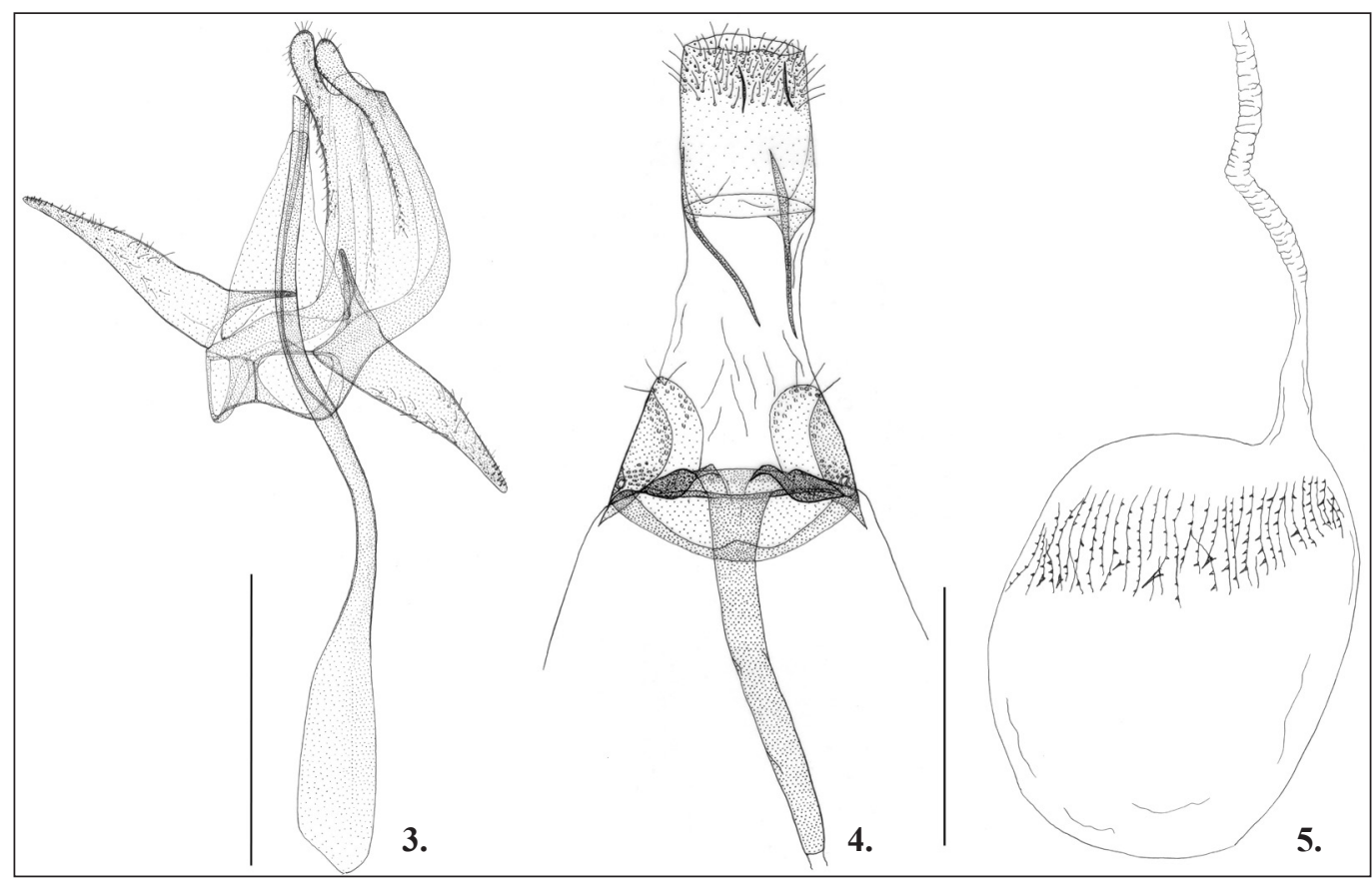

Figures 3-5. Male and female genitalia of Bucculatrix brunnella sp. n., paratypes. 3. Male genitalia, Gp. ZT ô 10762; 4-5. Female genitalia, TRB 3418 q; 4. dorsal view. 5. corpus bursae. Scale bars: $0.5 \mathrm{~mm}$.

Female genitalia (Figs 4-5). Papillae anales modified, posterior apophyses relatively short and narrow, anterior apophyses absent. Ostium circular edged with a pair of distinct curved sclerites. Sclerotized part of ductus bursae long and relatively straight, slightly tapering towards membranous part of ductus bursae of approximately the same length. Corpus bursae oval, signum in the form of spined ribs.

Diagnosis. The male of Bucculatrix brunnella sp. $\mathrm{n}$. is externally characterized by the almost monochrome ochreous to brown forewing with only an inconspicuous scattered pattern. It can resemble a monochrome form of B. cristatella (Zeller, 1839), but the colour of forewing of the latter species is pale ochreous grey.

In the male genitalia the new species significantly differs from any known species, in particular in the shape of the valva and socii lobes.

In the female genitalia the new species closely resembles those of B. mehadiensis Rebel, 1903 but both species differ significantly externally. The forewing of B. mehadiensis is creamy white with a striking blackish pattern, whilst the forewing ground colour of $B$. brunnella is ochreous to brown and a darker brown pattern is inconspicuous.

Biology. The early stages of the new species are unknown. Most of the adults were collected in light-traps between 8th and 23rd June and one specimen was taken on 21st September. The species probably has (at least) two generations a year.

Distribution and habitat (Fig. 6). Bucculatrix brunnella sp. n. is known from the islands of Sicily and Sardinia. In Sicily it was found in the north and north-eastern parts, mainly near Mount Etna. In Sardinia, it is so far only known from the Gennargentu Mountains. The species was collected from about 300 to $1100 \mathrm{~m}$ altitude. 


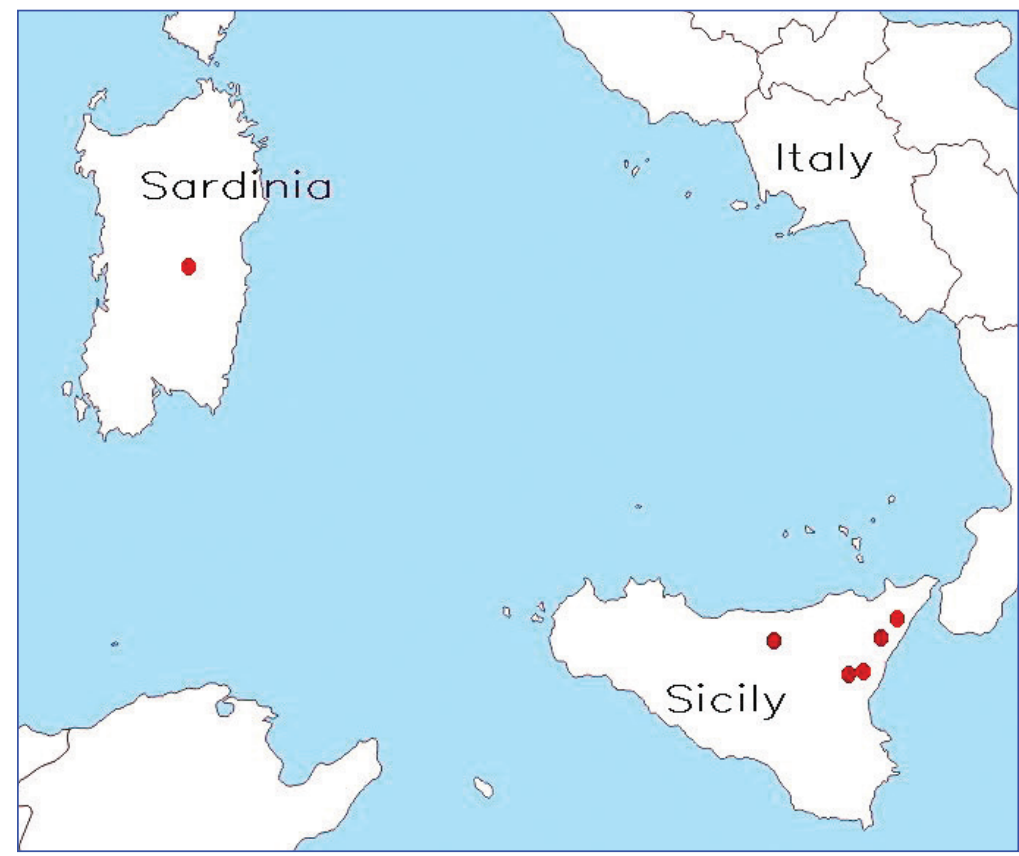

Figure 6. Map of distribution of Bucculatrix brunnella sp. n.

Etymology. The specific name brunnella is derived from the forewing colour of the new species.

Molecular data. An attempt to obtain DNA barcode sequences for five specimens of Bucculatrix brunnella sp. $\mathrm{n}$. was conducted at the Canadian Centre for Biodiversity Genomics. The records with BOLD sample IDs of MM19427, MM22860, MM22861, MM24276, MM24291 are preserved within the BOLD project "Bucculatricidae of Europe" (BUCEU) and are presently named as "Bucculatrix sp. 2". The voucher specimens are labelled with green labels, the codes without the prefix "MM" (Marko Mutanen), but only with the string of five numbers as shown above followed with "Lepid Phyl". However, the attempt at retrieving molecular data from the COI barcode region was unsuccessful.

\section{Discussion}

The discovery of Bucculatrix brunnella sp. $\mathrm{n}$. shows that the Mediterranean fauna of European Bucculatricidae is still insufficiently studied and can provide surprises. Despite the isolated geographic occurrence in Sicily and Sardinia, it can be assumed that the species lives also on Corsica or on other nearby islands in the Mediterranean Sea.

According to morphological characters the new species belongs to a large B. gnaphaliella (Treitschke, 1833) species group consisting of more than 100 species worldwide (Baryshnikova 2013).

In their development, species from the group specialized mostly on flowering plants in the Asteraceae. There are numerous closely related and morphologically poorly distinguishable species within this and other groups of Bucculatrix, suggesting that their differentiation occurred comparatively recently. Baryshnikova (2016) supposes that such differentiation is associated with the rise 
of dissimilarities in the mechanisms of attraction of individuals of the opposite sex and/or using different host-plants, but considers that it is difficult to know which evolutionary changes appeared first to trigger the speciation process.

For our new species it is obvious that its isolation from the mainland facilitated its speciation which resulted (as in the recently described species B. kaptarae Tokár, 2017 from Crete) in a higher degree of morphological differences from related species. We can only assume that - according to some of its morphological features and of the continental species B. humiliella Herrich-Schäffer, 1855 - they had a common ancestor before the separation of Sardinia and Sicily from their adjacent mainland.

\section{Acknowledgements}

Our thanks are due to Paolo Triberti (Verona, Italy) and Andreas Segerer (Munich, Germany) for providing specimens. The former also kindly provided genitalia slides and added valuable comments on the manuscript. Peter Huemer (Innsbruck, Austria) and Zdeněk Laštůvka (Brno, Czech Republic) are acknowledged for their advice on the manuscript. We thank Marko Mutanen (Oulu, Finland) for his assistance in carrying out the DNA analysis, and Robert J. Heckford (Plympton, U.K.) for checking and correcting the English of the manuscript and for helpful comments.

\section{References}

Baryshnikova SV (2013) Bucculatricid moths (Lepidoptera, Bucculatricidae) of the fauna of Russia and adjacent territories. Keys to the fauna of Russia published by the Zoological Institute of the Russian Academy of Sciences 175. KMK Scientific Press Ltd., St. Petersburg-Moscow, 160 pp. [In Russian]

Baryshnikova SV (2016) Morphological differentiation of closely related species of the genus Bucculatrix Zeller, 1839 (Lepidoptera, Bucculatricidae) with an analysis of their distribution and mechanisms of reproductive isolation. Entomological Review 96(6): 672-678. https://doi.org/10.1134/S0013873816060026

Mey W (2013) Fauna Europaea: Bucculatricidae. In: Karsholt O, Nieukerken EJ van (Eds) Fauna Europaea: Lepidoptera, Moths. Version 2017.06. http://www.fauna-eu.org

Pohl GR, Landry J-F, Schmidt BC, Lafontaine JD, Troubridge JT, Macaulay AD, Nieukerken EJ van, Waard JR de, Dombroskie JJ, Klymko J, Nazari V, Stead K (2018) Annotated checklist of the moths and butterflies (Lepidoptera) of Canada and Alaska. Pensoft Series Faunistica 118. Pensoft Publishers, Sofia, 580 pp.

Tokár Z (2017) Bucculatrix kaptarae sp. nov. (Lepidoptera: Bucculatricidae) from the mountains of western Crete. Entomologist's Gazette 68: 99-102. 